\title{
Sinergitas Pemerintah, Swasta dan Civil Society dalam Mewujudkan Kota Layak Anak di Kota Yogyakarta
}

\author{
Agista Siskasari $^{1}$, Awang Darumurti ${ }^{2}$, Ane Permatasari ${ }^{3}$ \\ ${ }^{1,2,3}$ Program Studi Ilmu Pemerintahan, Universitas Muhammadiyah Yogyakarta. Indonesia. \\ ${ }^{1}$ Email: Agistasiskasari@gmail.com
}

\begin{abstract}
Abstrak: Kota Layak Anak merupakan kabupaten/kota yang mempunyai sistem pembangunan berbasis hak anak melalui pengintegrasian komitmen dan sumber daya pemerintah, masyarakat, dan dunia usaha, yang terencana secara menyeluruh dan berkelanjutan dalam kebijakan, program dan kegiatan untuk menjamin terpenuhinya hak dan perlindungan anak. untuk mewujdukan Kota Layak Anak diperlukan Collaborative Governance melalui keterlibatan pemerintah, swasta dan civil society untuk bersama-sama mengupayakan pemenuhan hak anak. Penelitian ini bertujuan untuk mengetahui proses Collaboratuve Governance dalam pelaksanaan program Kampung Ramah Anak (KRA) dengan menggunakan pendekatan kualitatif deskriptif. Kampung Ramah Anak RW 07 Pakuncen telah melibatkan pemerintah, swasta dan civil society dalam melaksanakan program Kampung Ranah Anak (KRA).
\end{abstract}

Kata kunci: Collaborative Governance, Kota Layak Anak

Abstract: A Child Friendly City is a district / city that has a child rights-based development system through the integration of commitments and resources from the government, civil society and the Private Sector, which is planned comprehensively and sustainably in policies, programs and activities to ensure the fulfillment of children's rights and protection. To create a Child Friendly City, Collaborative Governance is needed through the involvement of the government, private sector and civil society to work together to fulfill children's rights. This study aims to determine the collaborative governance process in the implementation of the Child Friendly Village program using a descriptive qualitative approach. RW 07 Pakuncen Child Friendly Village has involved the government, private sector and civil society in implementing the Child Friendly Village program.

Keywords: Collaborative, Governance, child friendly city

Article History:

Received : 2020-05-14

Revised : 2020-6-16

Accepted : 2020-7-20

\section{PENDAHULUAN}

Indonesia adalah negara dengan ideologi pancasila sebagai dasar dalam kehidupan berbangsa dan bernegara bagi seluruh rakyat tanpa terkecuali. Pancasila yang tersirat di dalam pembukaan UUD 1945 juga menjadi sumber dari segala sumber hukum di Indonesia. Adanya aturan atau instrumen-intrumen hukum yang menopang bangsa ini difungsikan untuk mengatur kehidupan berbangsa dan bernegara. Selain itu adanya aturan-aturan diciptakan untuk menjaga ketertiban dan menyelaraskan kehidupann berkewarganegaraan serta untuk mewujudkan kesejahteraan bagi seluruh rakyat Indonesia sesuai dengan salah satu tujuan nasional bangsa Indonesia yaitu untuk memajukan kesejahteraan umum. Dalam rangka mewujudkan keberhasilan pembangunan kesejahteraan dan khususnya perlindungan anak, Indonesia telah meratifikasi sebuah perjanjian internasional yang disebut Konvensi Hak Anak (United Nations Convention on The Rights of The Child) yang bertujuan untuk menegakkan prinsip-prinsip pengakuan atas martabat yang melekat dan hak-hak yang sama pada manusia terutama anakanak untuk menciptakan kemerdekaan, keadilan dan perdamaian. Konvensi Hak Anak berlaku sebagai hukum internasional pada tahun 1989 kemudian diratifikasi di Indonesia yang berarti menandakan bahwa Indonesia telah sepakat secara politis dan yuridis pada 25 Agustus 1990 berdasar Keppres No 36 Tahun 1990. Konvensi Hak Anak mulai berlaku di Indonesia sejak 5 Oktober 1990. Hak Anak tidak bisa dipisahkan dari HAM dan Konvensi Hak Anak merupakan bagian yang tidak terpisahkan dari instrumen HAM. 
Konvensi Hak Anak merupakan salah satu intrumen internasional yang menjiwai berbagai kebijakan dan berbagai program pemenuhan hak anak dan perlindungan anak. Sosialisasi mengenai KHA hingga saat ini menjadi prioritas dan tanggungjawab pemerintah dalam rangka menumbuhkembangkkan kesadaran masyarakat akan pentingnya hak-hak anak. Pemerintah pusat, pemerintah daerah, organanisasi masyarakat dan juga swasta perlu mendapatkan pemahaman yang utuh mengenai hak-hak anak dan sejumlah konsep dasar yang terkait dengan konvensi hak anak. Negara yang telah meratifikasi KHA memiliki beberapa konsekuensi yang harus dilaksanakan diantaranya: a) Harus mensosialisasikan KHA kepada anak-anak, b) Negara membentuk aturan nasional mengenai hak-hak anak, c) Negara wajib membuat laporan mengenai implementasi KHA secara periodik setiap 5 tahun. Negara yang melanggar kesepakatan internasional tersebut dapat dikenai sansksi secara politis dan sanksi moral oleh negara-negara peserta lainnya. Bentuk sanksi berupa embargo, pengucilan, pemberian label negatif dan lain-lain.

Konvensi Hak Anak telah dikelompokkan beberapa poin yang disebut kluster. KHA memiliki 5 kluster diantaranya: a) Hak Sipil dan Kebebasan, b) Lingkungan Keluarga dan Pengasuhan Alternatif, c) Kesehatan Dasar dan Kesejahteraan, d) Pendidikan, Pemanfaatan Waktu Luang dan Kegiatan Seni Budaya, e) Perlindungan Khusus. Menindaklanjuti diratifikasinya Konvensi Hak Anak, pemerintah Indonesia dalam hal ini Kementerian Pemberdayaan Perempuan dan Perlindungan Anak Republik Indonesa mengembangkan sebuah kebijakan Kota Layak Anak yang tujuanya untuk mentransformasikan hak anak ke dalam proses pembangunan. Kebijakan mengenai Kota Layak Anak awal mula diperkenalkan pada tahun 2006. Dalam kebijakan Kota Layak Anak yang disingkat menjadi KLA tertuang upaya pemerintah kabupaten/kota untuk mempercepat implementasi Konvensi Hak Anak. . Dengan adanya kebijakan Kota Layak Anak diharapakan pemerintah baik pemerintah pusat maupun pemerintah daerah untuk meingkatkan kepedulian terhadap tumbuh kembang anak. Mengingat bahwa di dalam Konvensi Hak Anak terdapat 31 hak anak yang wajib dilindungi oleh negara. Di dalam Konvensi Hak Anak disebutkan bahwa anak-anak adalah seseorang yang berusia kurang dari 18 tahun. Anak-anak yang masih di dalam kandungan juga menjadi tanggung jawab negara untuk dilindungi haknya. Kebijakan mengenai Kota Layak Anak di Indonesia di dukung dengan adanya UU Perlindungan Anak Nomor 35 Tahun 2014.

Semakin tingginya angka kasus kekerasan yang terjadi pada anak-anak di Indonesia akan memberkan dampak buruk bagi masa depan bangsa. Anak-anak merupakan generasi yang akan melajutkan estafet kepemimpinan bangsa ini, mereka adalah tunas-tunas yang akan menjadi harapan untuk melanjutkan cita-cita dan tumpuan bagi majunya bangsa Indonesia. Jika anak Indonesia tidak dipersiapkan sedini mungkin maka boleh jadi akan mempengaruhi kualitas suatu bangsa. Untuk mengatasi hal demikian, Pemerintah Kota Yogyakarta berupaya mengimplementasikan Kebijakan Kota Layak Anak dengan membuat program-program yang dapat mendukung percepatan Kota Yogyakarta sebagai Kota Layak Anak. Pemerintah Kota Yogyakarta saat ini telah memiliki beberapa program yang diharpkan mampu memberikan informasi kepada masyarakat akan pentingnya pemenuhan hak anak sesuai dengan yang tertuang pada Konvensi Hak Anak. Sejak diperkenalkanya Kampung Ramah Anak pada tahun 2011, Pemerintah Kota Yogyakarta melalui Dinas Pemberdyaan Masyarakat Perempuan dan Perlindungan Anak (DPMPPA) membuat sebuah program berbasis kampung yang dinamakan Kampung Ramah Anak atau sering disebut KRA. Program berbasis kampung ini diharapkan dapat menciptakan lingkungan dan pola asuh yang ramah dan tentunya layak bagi anak. Pelaksanan program Kampung Ramah Anak membutuhkan dukungan dari berbagai pihak baik pemangku kebijakan di wilayah seperti, Kemantren/Kecamatan,Kapanewon/Kelurahan, Ketua RW, Ketua RT, Swasta/Pengusaha yang ada di wilayah dan tentunya dukungan dari masyarakat (civil society). Keberhasilan program Kampung Ramah Anak dapat dicapai dengan adanya Collaborative Governance antara pemerintah, swasta dan masyarakat. Kota Yogyakarta 
memiliki kampung binaan yang bervariasi dalam melaksanakan program Kampung Ramah Anak (KRA).

\section{METODE PENELITIAN}

Penelitian berjudul Sinergitas Pemerintah, Swasta dan Civil Society Dalam Mewujudkan Kota Layak Anak di Kota Yogyakarta Melalui Kampung Ramah Anak menggunakan metode kualitatif-deskriptif dengan tujuan untuk eksplorasi dan klarifikasi suatu kenyataan sosial. Penelitian ini dimaksukan untuk mengetahui proses collaborative government dalam pelaksanaan Program Kampung Ramah Anak di Kota Yogyakarta. Penelitian dilaksanakan pada bulan Desember hingga Januari dan berlokasi di Kampung Ramah Anak RW 07 Kapanewon Pakuncen, Kemantren Danurejan, Kota Yogyakarta. Wawancara akan dilakukan kepada pihak-pihak terkait yaitu Kepala Bidang Perlindungan Anak Dinas Pemberdayaan Perempuan, Masyarakat dan Perlindungan Anak Kota Yogyakarta (Fatmah Rosyati, S. IP) dan Penanggung jawab program KRA di RW 07 Pakucen (Ibu Asri Mikatsih, SIP) dan beberapa tokoh masyarakat serta warga yang menjadi sasaran dari program tersebut. Pertanyaan dalam wawancara akan dimulai dari pertanyaan umum dalam area yang luas pada penelitian dengan diikuti kata kunci atau daftar topik yang akan dicakup dalam wawancara. Selain itu frekuensi wawancara tiap partisipan tidak akan sama, tergantung pada proses wawancara dan jawaban dari tiap individu.

Observasi dilakukan dengan tujuan untuk mendeskripsikan program yang dilaksanakan, kegiatan yang dilaksanakan dan mengetahui orang-orang yang terlibat dalam suatu kegiatan dan makna dari kegiatan yang dilihat dari perspektif mereka yang terlihat dalam kegiatan yang diamati. Observasi dari penelitian ini berlokasi di wilayah RW 07 Pakuncen dan akan dilakukan dengan mengamati perkembangan program Kampung Ramah Anak serta kegiatan yang mendukung terwujudnya predikat Kota Layak Anak. Dokumen merupakan catatan kejadian atau peristiwa yang berupa tulisan, gambar, berita atau karya. Bukti fisik kegiatan akan menjadi sumber data yang dapat mendukung penelitian ini. Dokumentasi dari penelitian ini berupa foto-foto kegiatan yang dilaksanakan oleh Kampung Ramah Anak RW 07 Pakuncen. Selain itu dokumentasi dari penelitian ini dapat berupa notulen atau catatan kegiaan yang telah dilaksanakan oleh Tim Gugus Tugas KRA RW 07 Pakuncen. Analisis data dilakukan dengan melakukan penegasan terhadap tujuan penelitian kemudian mengembangkan pernyataan yang bersumber pada pedoman wawancara. Selanjutnya memberikan argumen secara umum dan kemudian menalami literatur yang berhubungan dengan data selama penelitian. Data yang bersumber dari observasi dan dokumentasi juga akan memberikan bukti serta penegasan argumen dalam penelitian.

\section{HASIL DAN PEMBAHASAN}

Program Kota/Kabupaten Layak Anak merupakan salah satu program yang bertujuan untuk menciptakan daerah yang aman, layak dan ramah bagi anak. Setelah pemerintah pusat melalui Kementrian Pemberdayaan Perempuan dan Perlindungan Anak Republik Indonesia (KPPPA RI) mengeluarkan program tersebut maka Pemerintah Kota Yogyakarta segera menindaklanjuti dengan membuat Peraturan Daerah Kota Yogyakarta Nomor 1 Tahun 2016 Tentang Kota Layak Anak. Mengingat jumlah kasus kekerasan pada anak di Kota Yogyakarta masih cukup tinggi. 
Tabel 1. Jumlah Korban Kekerasan Terhadap Anak yang Ditangani Menurut Jenis Kelamin, Usia, Tingkat Pendidikan, Pekerjaan, dan Status Perkawinan di DIY Tahun 2019

\begin{tabular}{|c|c|c|c|c|c|c|c|c|c|c|c|c|c|c|c|c|c|}
\hline \multirow[b]{2}{*}{ No. } & \multirow[b]{2}{*}{ Kabupate N/Kota } & \multirow[b]{2}{*}{ Junlah Unit Pelayanan Terpadu } & \multirow[b]{2}{*}{ Jumlah Kasus Baru } & \multicolumn{14}{|c|}{ Gri-Gri Kantun } \\
\hline & & & & \multicolumn{2}{|c|}{ Jenis Kelamin } & \multicolumn{3}{|c|}{ Usia } & \multicolumn{5}{|c|}{ Pendidian } & \multicolumn{2}{|c|}{ Pekeraan } & \multicolumn{2}{|c|}{ Status Pexarwinan } \\
\hline & 1 Kulon Progero & 7 & 69 & 22 & 47 & 10 & 13 & 96 & 25 & 16 & 23 & o & 0 & 62 & 7 & 69 & 0 \\
\hline & 3 Gunung Kodal & 5 & 4 & 1 & 3 & 0 & 0 & 4 & 0 & 3 & 1 & 0 & 0 & 4 & 0 & 4 & 0 \\
\hline & 4 Slamain & a & 141 & 63 & 78 & 24. & 30 & 37 & 74 & 27 & 28 & a & 0 & 134 & 7 & 137 & 4 \\
\hline & 5 Yizynaketa & 10 & $\underline{\underline{2} \mathbf{n}}$ & 23 & E6 & 7 & 20 & fi2 & 34 & 21 & 30 & a] & D. & ลด & 2 & ค9 & 1 \\
\hline & $S$ Pnasinsi & 6 & $=$ & $1 s$ & 30 & 11 & 19 & 29 & 26 & & 11 & iv & D. & 97 & 1 & 98 & d \\
\hline
\end{tabular}

Sumber Cata: EFFP/FPKK DNY

Data diatas menunjukkan bahwa kasus kekerasan di Kota Yogyakarata masih cukup tinggi. Oleh karena itu, Pemerintah Kota Yogyakarta melalui Dinas Pemberdayaan Masyarakat, Perempuan dan Perlindungan Anak Kota Yogyakarta terus berupaya untuk menciptakan daerah yang aman, ramah dan layak bagi anak melalui program Kampung Ramah Anak dengan tujuan melalui kampung-kampung yang ramah bagi anak maka tujuan utama untuk menciptakan Kota Layak Anak juga dapat tercapai. Selain itu, tujuan dari program Kampung Ramah Anak adalah untuk meminimalisir kasus kekerasan dari lingkup terkecil dengan berbasis kampung.

Collaborative Governance adalah sebuah proses pengaturan yang secara langsung melibatkan lebih dari satu badan publik termasuk lembaga non-pemerintah dalam pengambilan keputusan secara kolektif yang bersifat formal, berorientasi pada konsensus dan musyawarah untuk menghasilkan kebijakan publik. (Ansel \& Gash dalam Wargadinata 2016) Kemudian menurut Booher dalam Wargadinata, 2016 Collaborative Governance akan berhasil jika terjadi authentic dialogue yang melibatkan semua pihak untuk bersuara, berdiskusi untuk kepentingan bersama, berpikiran terbuka, menyadari posisi masing-masind dan adanya keinginan untuk mencari solusi yang berguna bagi semua pihak.

Kunci keberhasilan Collaborative Governance adalah keterlibatan berbagai komponen seperti pemerintah sebagai pemangku kebijakan, swasta/pengusaha dan masyarakat. Apabila hanya satu pihak saja yang menjalankan proses tersebut maka Collaborative Governance tidak bisa dicapai. Collaborative Governance dapat berupa pengambilan keputusan atau perumusan kebijakan publik, selain itu Collaborative Governance juga dapat berupa implementasi program maupun kegiatan yang ditentukan bersama-sama antara pemerintah, swaasta dan masyarakat.

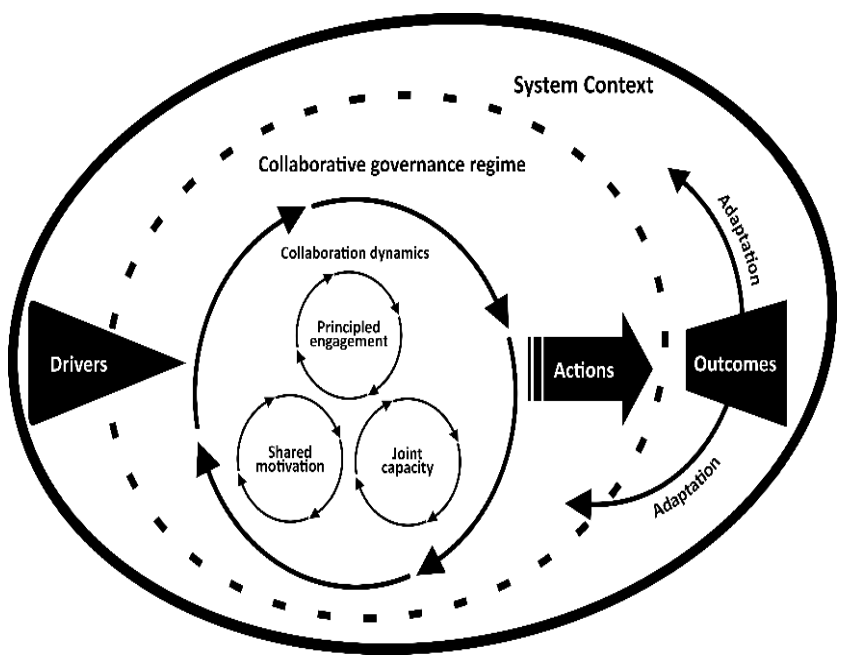

Gambar 1. Model Collaborative Governance (Kirk Emerson, Tina Nabatchi \& Stephen Balogh) 
Collaborative Governance menurut Kirk Emerson, Tina Nabatchi \& Stephen Balogh merupakan sebuah rangkaian interaktif yang kemudian menghasilkan dinamika kolaborasi atau collaborative dynamics yang didalamnya terdapat tiga indikator yaitu; a)Principled Engagement/Keterlibatan Berprinsip, b)Shared Motivation/Motivasi Bersama, c)Capacity For Join Action/Kapasitas Untuk Melakukan Aksi Bersama. Setelah terjadi collaboration dynamics maka akan ada action yang kemudian menghasilkan outcomes.

Proses keterlibatan swasta dalam pelaksanaan program Kampung Ramah Anak RW 07 Pakuncen didasari karena adanya keinginan untuk meningkatkan kepedulian terhadap lingkungan sekitar seperti yang dilakukan oleh Lembaga Bimbingan Belajar Primagama dan Waroeng Steak and Shake. Berdasar hasil wawancara kepada Ibu Asri selaku penanggungjawab program Kampung Ramah Anak RW 07 Pakuncen, usaha yang bergerak di bidang Pendidikan dan kuliner tersebut justru menawarkan kepada pengurus wilayah untuk memberikan bantuan didasari oleh adanya kepedulian terhadap lingkungan. Selain itu, keterlibatan swasta dalam kegiatan kampung diawali dengan adanya aksi bersama berupa kegiatan donasi sosial yang kemudian berlanjut hingga adanya kolaborasi dalam kegiatankegiatan lainnya salah satunya kegiatan yang menjadi program Kampung Ramah Anak.

Tabel 2. Profil Anak RW 07 Pakuncen Tahun 2016

\begin{tabular}{lccc}
\hline \multicolumn{1}{c}{ Usia } & Laki-Laki & Perempuan & Jumlah \\
\hline Balita (0-5 Tahun) & 25 & 21 & 46 \\
\hline Taman Kanak-Kanak & 2 & 5 & 7 \\
\hline Sekolah Dasar & 22 & 27 & 49 \\
\hline Sekolah Menengah Pertama & 15 & 19 & 34 \\
\hline Sekolah Menengah Atas & 13 & 10 & 23 \\
\hline \multicolumn{1}{c}{ TOTAL } & 77 & 82 & 159 \\
\hline
\end{tabular}

Data diatas menunjukkan bahwa anak-anak di RW 07 Pakuncen mayoritas balita dan anak sekolah dari SD hingga SMA. Dengan data diatas maka Tim Gugus Tugas KRA dapat menyusun kegiatan sesuai dengan kebutuhan anak-anak di wilayah setempat. Berbagai kegiatan yang dilaksanakan di RW 07 Pakuncen terintegrasi dengan program Kampung Ramah Anak. Proses Collaborative Governance diawali pada tahun 2016 ketika Tim Gugus Tugas Kampung Ramah Anak melaksanakan kegiatan 'Belajar di Luar Lingkungan yang melibatkan Pemerintah, Swasta dan Masyarakat kegiatan tersebut diikuti oleh anak-anak usia SD. Selain itu, kegiatan RW 07 Pakuncen yang melibatkan tiga komponen dalam Collaborative Governance adalah kegiatan pemberian gizi balita melalui posyandu. Secara rutin, Waroeng Steak and Shake menyubsidi PMT (Pemberian Makanan Tambahan) bagi balita sehingga masyarakat merasa terbantu karena adanya subsidi secara rutin.

Keterlibatan pemerintah, swasta dan masyarakat secara kolaboratif di RW 07 Pakuncen juga ada di bidang pendidikan yaitu berupa les gratis. Fasilitas les gratis diberikan oleh Lembaga Bimbingan Belajar Primagama. Berdasar wawancara kepada Ibu Asri selaku penanggung jawab program Kampung Ramah Anak, pemberian fasilitas gratis memang murni atas kepedulian terhadap lingkungan, jutru pihak Lembaga Bimbingan Belajar Primagam yang menawarkan program les gratis bagi anak-anak RW 07 Pakuncen. Tawaran tersebut disampaikan oleh kepala cabang kepada Ibu Asri. Program les gratis diberikan kepada anak usia SD, SMP \& SMA dan jumlahnya tidak dibatasi. Menurut keterangan Ibu Asri, setiap menjelang ujian sekolah, Lembaga Bimbingan Belajar Primagama selalu menguhubungi Tim Gugus Tugas KRA untuk mendaftarkan anak-anak RW07 Pakuncen agar mengikuti les gratis tersebut. 
Pelaksanaan program Kampung Ramah Anak RW 07 Pakuncen telah mengimplementasikan konsep Collaborative Governance. Tim Gugus Tugas Kampung Ramah Anak RW 07 Pakuncen melibatkan pemerintah, swasta dan masyarakat dalam pelaksanaan program KRA. Setelah mengalami masa vakum dari tahun 2011 hingga tahun 2016 maka Tim Gugus Tugas Kampung Ramah anak bertekad untuk menggiatkan kembali kegiatan yang menjadi program dari KRA RW 07 Pakuncen.

\section{Proses Collaborative Governance (Collaboration Dynamics) RW 07 Pakuncen: Principled Engagement}

Pada indikator keterlibatan berprinsip, pemerintah berperan sebagai fasilitator yang menyediakan fasilitas dan membantu masyarakat untuk merancang rencana dalam mencapai tujuan dari Kampung Ramah Anak. Sebagai fasilitator pemerintah juga bertugas untuk menciptakan kondisi yang kondusif bagi pelaksanaan program Kampung Ramah Anak serta membentuk Tim Gugus Tugas Kampung Ramah Anak. . Keterlibatan berprinsip swasta dapat dilihat dari kepedulian dan konsistensinya dalam memberikan bantuan dan memberikan fasilitas kepada warga RW 07 baik berupa Pemberian Makanan Tambahan (PMT) maupun fasilitas les gratis dari pihak swasta yang memiliki perusahaan di wilayah RW 07 Pakuncen. Kemudian prinsip keterlibatan masyarakat dapat dilihat dari antusiasme masyarakat saat mengikuti berbagai kegiatan yang menjadi program kerja Tim Gugus Tugas KRA RW 07 Pakuncen.

\section{Shared Motivation}

Adanya motivasi bersama antara pemerintah, swasta dan masyarakat sangat mempengaruhi keberhasilan dalam collaborative governance. Dinas Pemberdayaan Masyarakat, Perempuan dan Perlindungan Anak secara berkala melakukan monitoring pada saat pelaksanaan kegiatan Kampung Ramah Anak sehingga dengan adanya monitoring dan dukungan fasilitas pemerintah maka masyarakat dan pengusaha setempat lebih antusias dan tertarik untuk berkolaborasi untuk melaksanakan berbagai kegiatan dalam program Kampung Ramah Anak. Motivasi swasta dilihat dari adanya keterlibatan swasta secara langsung pada saat pelaksanaan kegiatan, selain itu juga dapat dilihat dari adanya kepedulian yang ditandai dengan adanya inisiatif dari swasta untuk memberikan tawaran bantuan kepada pengurus wilayah baik bantuan berupa les gratis bagi anak-anak RW 07 Pakuncen maupun bantuan berupa pemberian PMT saat posyandu. Proses collaborative governance di RW 07 Pakuncen juga didukung dengan adanya motivasi dari masyarakat untuk bersama-sama mendukung program Kampung Ramah Anak. Seluruh lapisan masyarakat dari beragam usia anak-anak, remaja hingga dewasa sangat mendukung program Kampung Ramah Anak.

\section{Capacity For Join Action}

Kolaborasi antara pemerintah, swasta dan masyarakat di KRA RW 07 Pakuncen melibatkan partisipasi secara langsung pemerintah, swasta dan masyarakat. Dengan adanya keterlibatan langsung atau partisipasi secara langsung dari pemerintah, swasta dan masyarkat maka seluruh komponen yang terlibat kolaborasi memiliki kapasitas untuk melakukan aksi bersama walaupun keterlibatannya berbeda-beda. Meskipun dalam kegitan yang berbeda-beda namun pemerintah dan swasta telah menunjukkan kesediaan untuk turut dalam kegiatan yang dilaksanakn oleh Tim Gugus Tugas KRA. Dinas Pemberdayaan Masyarakat Perempuan dan Perlindungan Anak memiliki kapasitas untuk terlibat dalam kegiatan yang sifatnya formal atau ceremonial sedangkan swasta dapat terlibat dalam kegiatan yang pelaksanaanya rutin seperti saat posyandu yang dilaksanakan setiap tannggal 4 di setiap bulannya dan pada momen kenaikan kelas dengan memberikan fasilitas les gratis untuk anak-anak. yang berada di wilayah RW 07 Pakuncen. 


\section{Kegiatan interaktif dalam collaborative governance Partisipasi Pemerintah, Swasta dan Masyarakat}

Pelaksanaan program Kampung Ramah Anak di RW 07 Pakuncen telah berhasil melibatkan tiga komponen yaitu pemerintah, swasta dan masyarakat. Ketiganya mengambil peran yang berbeda-beda dalam menciptskan ksmpung yang ramah bagi anak. Partisipasi dari ketiga komponen tersebut kemudian membentuk sebuah collaboration dynamic sesuai dengan teori Kirk Emerson, Tina Nabatchi \& Stephen Balogh.

\section{Keterbukaan}

Menurut keterangan Tim Gugus Tugas KRA, dalam melaksanakan kegiatan yang melibatkan pemerintah swasta dan masyarakat, pengurus memberikan laporan kepada pemerintah dan juga kepada swasta. Bentuk pelaporan kegiatan yang diberikan kepada pemerintah menggunakan format khusus berupa notulen dan laporan kegiatan secara formal. Kemudian untuk pelaporan kegiatan kepada swasta hanya berupa bukti foto kegiatan. Pengurus wilayah selalu memberikan laporan kepada pemerintah, pada pihak swasta dan juga memiliki arsip berupa bukti kegiatan yang teah diaksanakan

\section{Pola Komunikasi}

Pola komunikasi antara pengurus wilayah kepada pemerintah, swasta dan masyarakat dilaksanakan secara dua arah, artinya antara pengurus dengan ketiga komponen tersebut memang terjadi kegiatan interaktif baik melalui lisan maupun tulisan. Dengan adanya komunikasi yang baik antara pengurus wilayah, pemerintah, swasta dan masyarakat akan mempengaruhi keberhasilan proses collaborative governance karena komunikasi menjadi bagian yang sangat penting dalam suatu kelompok/organisasi untuk mencapai tujuan bersama. Tim Gugus Tugas KRA RW 07 Pakuncen membangun pola komunikasi melalui penanggungjawab program sehingga komunikasi dengan pemerintah dan swasta melalui seorang penanggungjawab yang bertugas untuk menjaadi humas. Kemudian komunikasi dengan masyarakat dilakukan melalui adanya pemberitahuan kepada warga baik secara lisan maupun tulisan.

\section{Implementasi Kota Layak Anak}

Kabupaten/Kota Layak Anak adalah kabupaten/kota yang mempunyai sistem pembangunan berbasis hak anak melalui pengintegrasian komitmen dan sumber daya pemerintah, masyarakat, dan dunia usaha, yang terencana secara menyeluruh dan berkelanjutan dalam kebijakan, program dan kegiatan untuk menjamin terpenuhinya hak dan perlindungan anak. Tujuan Kabupaten/Kota Layak Anak secara umum adalah untuk memenuhi hak dan melindungi anak kemudian secara khusus bertujuan untuk membangun inisiatif pemerintah kabupaten/kota yang mengarah pada transformasi Konvensi Hak Anak (Convention on the Rights of the Child) dari kerangka hukum ke dalam definisi, strategi, dan intervensi pembangunan, dalam bentuk : kebijakan, program dan kegiatan pembangunan yang ditujukan untuk pemenuhan hak dan perlindungan anak pada suatu wilayah kabupaten/kota. Prinsip implementasi Kota Layak Anak sesuai Konvensi Hak Anak :

\section{Kepentingan Terbaik Untuk Anak}

Dalam menyusun kebijakan dan melaksanakan program, pemerintah harus mengupayakan kepentingan terbaik bagi anak. Seluruh aspek dalam pelaksanaan program harus ada keberpihakan pada anak. Begitu pula pelaksanaan program Kampung Ramah Anak RW 07 Pakuncen, seluruh kegiatan maupun penyediaan sarana prasarana juga mengupayakan kepentingan terbaik untuk anak. di wilayah RW 07 Pakuncen terdapat Ruang Terbuka Hijau (RTH) yang di lengkapi dengan area bermain dan fasilitas bermain bagi anak, di lokasi tersebut 
juga dilengkapi dengan poster yang berisi informasi tentang pemenuhan hak anak. RTH yang menjadi area bermain anak juga bebas dari asap rokok sehingga pemanfaatan ruang publik tersebut memang mengupayakan kepentingan terbaik bagi anak.
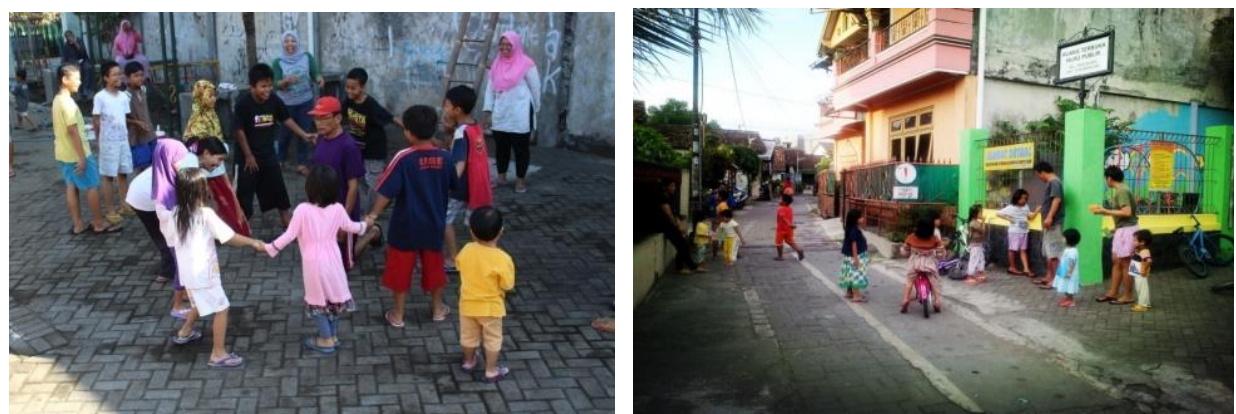

Gambar 2. Kegiatan Anak di Ruang Terbuka Hijau (RTH)

\section{Penghargaan Terhadap Pendapat Anak}

Program Kampung Ramah Anak merupakan program yang secara langsung melibatkan anak anak dari awal pembentukan pengurus, penyusunan program kerja hingga pelaksanaan kegiatan. Pendapat anak merupakan prioritas dalam pelaksanaan program Kampung Ramah Anak. Anak-anak diberi wadah untuk menyampaikan aspirasi melalui Forum Anak "Wista" yang anggotanya merupakan anak-anak RW 07 Pakuncen yang berusia dibawah 18 tahun. Forum tersebut dibentuk bersamaan dengan dibentuknya Tim Gugus Tugas KRA. Anak-anak diberi ruang untuk berpendapat menympaikan ide dan gagasan dalam pelaksanaan program Kampung Ramah Anak RW 07 Pakuncen. Salah satu kegiatan yang berasal dari ide dan gagasan anak-anak adalah kegiatan melukis dinding atau mural. Kegiatan tersebut merupakan kegiatan dari anak, untuk anak dan oleh anak. kegiatan dilaksanakan di Ruang Terbuka Hijau dimana tempat tersebut merupakan tempat bermain dan berkegiatan bagi anak-anak RW 07 Pakuncen.
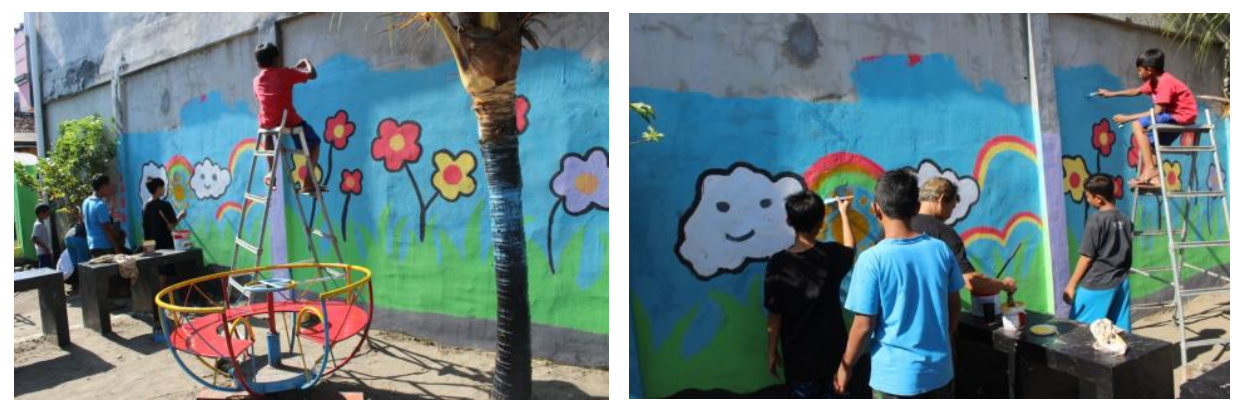

Gambar 3. Kegiatan Mural di Ruang Terbuka Hijau

\section{Non Diskriminasi}

Pada setiap kegiatan yang melibatkan anak-anak, baik Tim Gugus Tugas KRA maupun Forum Anak menerapkan prinsip pemenuhan hak anak dengan tidak membeda-bedakan latar belakang, agama, suku, dan status sosial yang artinya seuluruh anak memiliki hak yang sama untuk dapat mengikuti kegiatan yang menjadi program kerja dari Kampung Ramah Anak. Selain itu, keanggotaan forum anak juga menerapkan prinsip non diskriminasi dimana seluruh anak di wilayah RW 07 Pakuncen dapat bergabung dengan forum anak dengan syarat berusia dibawah 18 tahun karena menurut Undang-Undang Perlindungan Anak Nomor 35 Tahun 2014, anak adalah seseorang yang belum berusia 18 tahun. Kegiatan les gratis yang diberikan gratis oleh lembaga bimbingan belajar Primagama juga menerapkan prinsip non diskriminasi dimana seluruh anak-anak di wilayah RW 07 Pakuncen yang akan menempuh ujian diperbolehkan mendaftar untuk mengikuti les gratis melalui Tim Gugus Tugas KRA. 


\section{Kelangsungan Hidup dan Perkembangan}

Prinsip kelangansungan hidup dan perkembangan juga sesuai dengan hak anak, orang tua wajib menjamin kelangsungan hidup dan perkembangan anak. seperti yang tertuang dalam 4 hak dasar anak siantaranya : 1) Hak Hidup, 2) Hak Tumbuh Kembang, 3) Hak Perlindungan, 4) Hak Partisipasi. Dalam menegakkan prinsip kelangsungan hidup dan perkembangan, negara juga wajib hadir dan bertanggung jawab. Adanya kegiatan berupa les gratis dan Pemberian Makanan Tambahan (PMT) pada saat posyandu merupakan salah satu wujud kegiatan yang bertujuan untuk menegakkan prinsip kelangsungan hidup dan perkembangan yang dilaksanakan secara collaborative antara pemerintah, swasta dan masyarakat. Selain itu, kegiatan yang mendukung prinsip kelangsungan hidup dan perkembangan adalah adanya Paud "Pintar" yang dilaksanakan secara rutin dan diikuti oleh anak-anak usia dini di wilayah RW 07 Pakuncen.

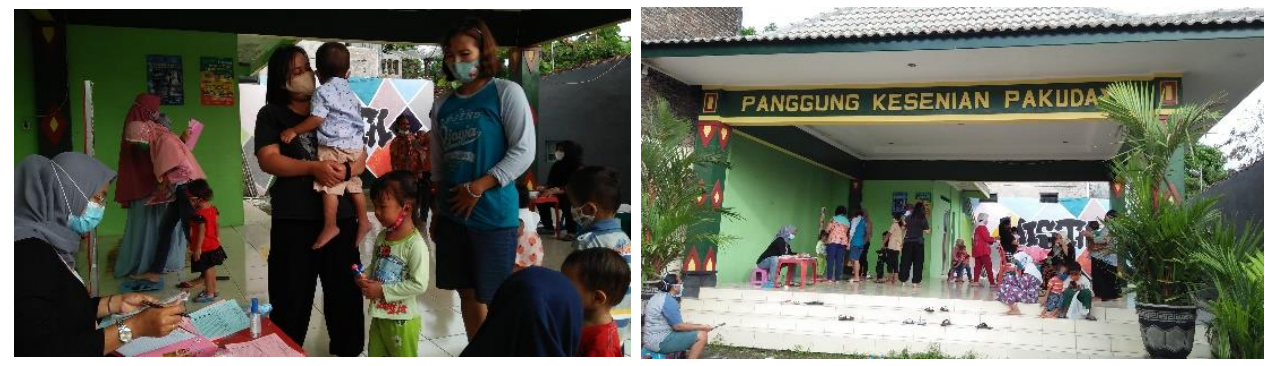

Gambar 4. Kegiatan Posyandu Balita

Gambar 4. diatas merupakan kegiatan posyandu balita yang secara rutin dilaksanakan pada tanggal 4 di setiap bulannya. Kegiatan posyandu secara rutin dipantau oleh Dinas Kesehatan dengan adanya bidan yang mendampingi serta memastikan seluruh anak terpantau pertumbuhannya melalui kegiatan posyandu Di masa pandemi covid-19, posyandu balita menjadi salah satu kegiatan yang tetap dilaksanakan tentunya dengan menerapkan protokol kesehatan. Balita dan ibu yang datang ke posyandu wajib menggunakan masker, menjaga jarak dan pengurus juga menyediakan handsanitizer. Namun yang menjadi kekurangan dari kegiatan posyandu balita di masa pandemi adalah belum adanya pengecekan suhu tubuh bagi ibu dan balita yang datang ke posyandu.

Upaya pemenuhan hak anak merupakan tugas bersama, baik pemerintah, swasta maupun masyarakat. Program Kampung Ramah Anak di RW 07 Pakuncen telah melibatkan Dinas Pemberdayaan Masyarakat, Perempuan dan Perlindungan Anak (DPMPPA) dalam kegiatan yang terintegrasi dengan program Kampung Ramah Anak serta melibatkan Dinas Kesehatan yang berperan dalam memantau tumbuh kembang anak melalui posyandu balita yang dilaksanakan secara rutin. Selain itu, Swasta juga memiliki keterlibatan dalam pemenuhan hak anak dengan adanya bantuan PMT (Pemberian Makanan Tambahan) saat posyandu dari Waroeng Steak \& Shake dan fasilitas les gratis dari Bimbingan Belajar Primagama. Tidak hanya itu, Muhammadiyah sebagai civil society juga turut berperan dalam upaya pemenuhan hak anak melalui kegiatan sosialisasi dan edukasi bagi masyarakat tentang pentingnya ketahanan keluarga yang dilaksanakan oleh Pimpinan Cabang Aisyiyah Wirobrajan. Sosialisasi dan edukasi tentang pentingnya ketahanan keluarga dilakukan bersamaan dengan kegiatan pengajian rutin yang dilaksanakan di masjid yang berlokasi di wilayah RW 07 Pakuncen. Dengan adanya kegiatan tersebut maka, Muhammadiyah sebagai civil society turut berpartisipasi dalam upaya pemenuhan hak anak di RW 07 Pakuncen. Secara umum masyarakat telah memahami upaya pemenuhan hak anak namun tidak menutup kemungkinan masih ada masyarakat yang belum mengupayakan pemenuhan hak anak. Tetapi itu semua dapat teratasi dengan adanya program Kampung Ramah Anak. Tim Gugus Tugas KRA 
bertanggungjawab untuk memastikan bahwa anak-anak di wilayah RW 07 Pakuncen terpenuhi hak-haknya.

Proses collaborative yang telah terlaksana dengan baik pada program Kampung Ramah Anak RW 07 Pakuncen menjadi poin plus saat penilaian atau evaluasi KRA yang dilaksanakan oleh Dinas Pemberdayaan Masyarakat, Perempuan dan Perlindungan Anak. KRA Award merupakan apresiasi yang diberikan kepada kampung ramah anak yang berhasil melaksnakan program dengan baik, konsisten dan aktif dalam pemenuhan hak anak. RW 07 Pakuncen menjadi salah satu dari tiga peraih Kampung Ramah Anak pada Tahun 2017. Proses Collaborative Governance menjadi sorotan yang menarik karena kampung-kampung yang lain belum dapat mengimplementasikan Collaborative Governance dalam pelaksanaan program KRA. Keberadaan KRA yang jumlahnya mencapai 193 juga menjadi pendorong percepatan KLA sehingga setiap tahunnya Kota Yogyakarta dapat meraih penghargaan secara progresif. Saat ini Kota Yogyakarta telah mendapat predikat Nindya untuk kemudian berlanjut hingga memperoleh predikat Kota Layak Anak tentunya dengan meningkatkan kepedulian terhadap anak dan upaya pemenuhan hak anak baik ditingkat kota maupun di lingkup terkecil melalui Kampung Ramah Anak.

Kegiatan interaktif dalam collaborative governance dapat berjalan dengan baik karena adanya dukungan pemerintah dan kepedulian dari pihak swasta yang berlokasi di wilayah RW 07 untuk turut berpartisipasi dan memberikan bantuan kepada warga setempat. Selain itu, keberhasilan collaborative governance juga dipengaruhi oleh peran Tim Gugus Tugas Kampung Ramah Anak yang aktif dalam melaksanakan kegiatan yang berkaitan dengan pemenuhan hak anak dan perlindungan anak. Partisipasi pemerintah, swasta dan masyrakat sangat mempengaruhi kegiatan interaktif dalam collaborative governance. Kemudian adanya pola komunikasi antara pihak yang terlibat dalam kolaborasi dan keterbukaan dalam pelaksanaan program KRA di RW 07 Pakuncen juga mempengaruhi keberhasilan proses collaborative governance. Namun, komunikasi yang baik saja tidak cukup untuk meraih keberhasilan proses collaborative governance, hingga saaat ini, koordinasi antar stakeholder masih menjadi kelemahan dalam proses collaborative governance di RW 07 Pakuncen. Berbagai kegiatan yang dilaksanakan di RW 07 Pakuncen juga sesuai dengan prinsip penegakan Hak Anak menurut Konvensi Hak Anak. Program Kampung Ramah Anak dapat meningkatkan pemahaman masyarakat akan pentingnya pemenuhan hak anak dan perlindungan anak. Keberhasilan proses collaboration governance antara pemerintah, swasta dan masyarakat dalam pelaksanaan program kampung ramah anak di RW 07 Pakuncen berbuah hasil berupa penghargaan KRA Award Tahun 2017 yang diberikan oleh Dinas Pemberdayaan Masyarakat, Perempuan dan Perlindungan Anak. Pemerintah berharap, kampung-kampung yang lain dapat termotivasi untuk menggandeng 3 komponen yaitu pemerintah, swasta dan masyarakat dalam pelaksanaan program KRA karena semakin banyak collaborative governance dalam pelaksanaan program Kampung Ramah Anak maka akan mempercepat terwujudnya Kota Layak Anak di Kota Yogyakarta.

\section{KESIMPULAN DAN SARAN}

Proses Collaborative Governance dalam pelaksanaan program Kampung Ramah Anak RW 07 Pakuncen telah dilaksanakan dengan adanya kegiatan interaktif sesuai teori Kirk Emerson, Tina Nabatchi \& Stephen Balogh. Indikator Shared Motivaton/Motivasi Bersama antara pemerintah, swasta dan masyarakat telah berjalan dengan baik karena ketiganya memiliki kemauan dan keinginan untuk melakukan kegiatan dalam upaya pemenuhan hak anak tanpa adanya paksaan dari pihak manapun. Kemudian pada indikator Capacity For Join Action/Kapasitas Untuk Melakukan Aksi Bersama telah terlaksana dengan adanya kegiatan yang melibatkan pemerintah, swasta dan masyarakat. Indikator yang harus diperbaiki adalah Principled Engagment/Keterlibatan Berprinsip karena tidak adanya bentuk komitmen tertulis 
secara resmi sehingga prinsip keterlibatan hanya berjalan begitu saja tanpa adanya perjanjian hitam diatas putih. Hal ini cukup menjadi kendala bagi keberlangsungan collaborative governance. Dengan adanya komitmen resmi maka antara pemerintah, swasta dan masyarakat telah memiliki pemahaman yang sama mengenai konsep collaborative gocernance yang akan dijalankan sehingga keberlangsungan dapat terkonsep dengan baik.

Komitmen antara pemerintah, swasta dan masyarakat merupakan pilar dalam pelaksanaan collaborative governance. Seluruh indikator dapat berjalan dengan baik karena adanya komitmen dari masing-masing pihak yang terlibat. Namun yang menjadi kelemahan dari proses collaborative governance di RW 07 Pakuncen adalah tidak adanya komitmen resmi hitam diatas putih sehingga komitmen hanya dibangun atas dasar rasa saling percaya dan komitmen tanpa adanya perjanjian resmi. Proses Collaborative Governance dalam pelaksanaan program Kampung Ramah Anak sebaiknya dilaksanakan dengan adanya komitmen resmi yang tertulis misalnya dengan melakukan MoU (Memorandum of Understanding). Kerjasama yang diperkuat dengan adanya komitmen secara resmi dan tertulis dapat dipertanggungjawabakan sehingga proses collaborative governance juga dapat terkonsep dengan matang dan lebih jelas. Dikarenakan lemahnya koordinasi dan tidak ada bentuk komitmen secara resmi maka proses collaborative governance dapat terhenti begitu saja karena tidak ada kesepakatan yang jelas. Selain itu, sebaiknya pelaksanaan collaborative governance dalam pelaksanaan program Kampung Ramah Anak juga disertai dengan pelaporan secara berkala dengan format resmi karena dengan adanya pelaporan resmi secara rutin dan dikumpulkan menjadi sebuah dokumen tertulis maka akan meningkatkan dukungan dan akan menambah kepercayaan pemerintah, swasta serta masyarakat.

\section{DAFTAR PUSTAKA}

Bagaskara, Sewitra., Dra. Dyah Lituhayu, M. Si. Formulasi Kebijakan Perlindungan Anak di Kota Semarang. Departemen Administrasi Publik Fakultas Ilmu Sosial dan Ilmu Politik Universitas Diponegoro

Chan, Loritta., et all. (2016). A City Fit for Children: Mapping and Analysis of Child Friendly Cities Initiatives. The Chinese University Of Hong Kong Faculty Of Law. Research Paper No. 2016-35

Dewi, Siti Malaiha. (2011). Transformasi Kudus Sebagai Kota Layak Anak (Tinjauan Atas Pemenuhan Hak Sipil dan Partisipasi). MUWAZAH. Vol. 3., No. 1.

Duadji, N \& Tresiana, N. (2018). Kota Layak Anak Berbasis Collaborative Governance. Jurnal Studi Gender. Vol. 13., No. 1

Fauzi, Agung \& Rahayu, Amy. 2019. Pencegahan HIV/AIDS Melalui Collaborative Governance Antara Pemerintah, Lembaga Swadaya Masyarakat dan Masyarakat. Jurnal Inspirasi. BPSDM Provinsi Jawa Barat. Vol 10, No 1

Hamudy, Moh Ilham. (2015). Upaya Mewujdukan Kota Layak Anak Di Surakarta dan Makassar. Jurnal Bina Praja. Volume 7 Nomor 2 Edisi Juni 2015 : 149 - 160

Irawan, Denny. (2017) Collaborative Governance (Studi Deskriptif Proses Pemerintahan Kolaboratif Dalam Pengendalian Pencemaran Udara di Kota Surabaya). Repository Universitas Airlangga

Kuriasari, Alit. (2016). Faktor Risiko di Kalangan Anak Yang Menjadi Korban Eksploitasi Seksual di Kota Surabaya. SOSIO KONSEPSIA. Vol. 5,. No. 03.

Manurung, Surtha. (2018) Collaborative Governce Dalam Mencapai Program Wajib Belajar di Kecamatan Cidadap. Repository Universitas Katolik Parahyanagan

Mulyadi, Didi. (2016). Implemenasi Kebijakan Pengembangan Kota Layak Anak Bidang Pendidikan di Kota Yogyakarta Tahun 2015 (Studi Kasus : Dinas Pendidikan Kota 
Yogyakarta Tahun 2016). Prodi Ilmu Pemerintahan Universitas Muhammadiyah Yogyakarta.

Prasetyo, M Irwan. (2013). Evaluasi Kebijakan Sidoarjo Kota Ramah Anak di Kecamatan Krembung, Kabupaten Sidoarjo. Kebijakan dan Manajemen Publik. Vol. 1., No. 1.

Ratri, Dewi. (2014). Implementasi Peraturan Walikota Nomor 36 Tahun 2013 Tentang Kebijakan Kota Layak Anak. Jurnal OF Governance And Policy. Vol. 1., No. 2.

Reisdian, Rangga., M. Saleh Soeadiy, Sukanto. Implementasi Kebijakan Pegarusutamaan Hak Anak Dalam Rangka Mewujudkan Kabupaten Layak Anak. (Studi Kasus Kepada Badan Pemberdayaan Perempuan dan Keluarga Berencana Kabupaten Jombang). Jurnal Administrasi Publik. Vol. 1., No. 6

Rizki, Devi Ayu., Sri Sulasti, Maulana Irfan. Pemenuhan Hak Partisipasi Anak Melalui Forum Anak Dalam Implementasi Kebijakan Kota Layak Anak Kota Bandung (Studi Kasus Forum Komunkasi Anak Bandung). Share Social Work Jurnal. Vol. 5, . No.1.

Rumtianing, Irrma. (2014). Kota Layak Anak Dalam Perspektif Perlindungan Anak. Jurnal Ilmiah Pendidikan Pnacasila dan Kewarganegaraan. Vol. 27., No. 1.

Subiyakto, Rudi. (2012). Membangun Kota Layak Anak : Studi Kebijakan Publik di Era Otonomi Daerah. Sosio-Religia.Vol. 10,. No. 1.

Subussalam, M Dhia., Murtanti J R, Rizon P. (2015). Peran Pelayanan Sekolah Dasar Dalam Mendukung Kota Layak Anak di Surakarta. Arsitektura. Vol. 13., No. 2

Tando, Cahyoko. dkk. (2016) Pemerintahan Kolaboratif Sebagai Solusi Kasus Defortasi Di Pulai Kalimantan : Kajian Literatur. Jurnal Borneo Adminitrator. Vol 15., No 3.

Wargadinata, Ella. 2016. Kepemimpinan Kolaboratif. Jurnal Administrasi Pemerintagan Daerah. Vol 8, Edisi

Woodhouse, B Bennett. (2009). A World Fit for Children Is a World Fit for Everyone: Ecogenerism, Feminism, and Vulnerability. Heinonline : 46 Hous. L. Rev. 817.

jogjakota.go.id

kemenpppa.go.id

siga.jogjaprov.go.id

unicef.org

Undang-Undang Nomor 35 Tahun 2014

Peraturan Daerah Kota Yogyakarta Nomor 1 Tahun 2016

Peraturan Walikota Yogyakarta Nomor 71 Tahun 2018

Perwaturan Walikota Yogyakarta Nomor 4 Tahun 2020 